\title{
Outbreak of Aseptic Meningitis due to ECHO-9 in Northern Kyushu Island in the Summer of 1997
}

\author{
YUKO AKASU
}

\begin{abstract}
Departments of Pediatrics and Child Health and Virology, Kurume University School of Medicine, Kurume 830-0011, Japan
\end{abstract}

\begin{abstract}
Summary: An outbreak of aseptic meningitis caused by echovirus type 9 (ECHO-9) occurred between June and August 1997 in the Chikugo area, Fukuoka, Japan. Clinical manifestations and laboratory data of 317 children with aseptic meningitis were analyzed. The age of the patients ranged from 1 month to 12 years with the highest incidence in 4 years old children. The male: female ratio was 2.0:1.0. Symptoms of the meningitis included fever $(100 \%)$, headache $(89.5 \%)$ and nausea and/or vomiting (85.6\%). Skin rash was not frequent $(2.2 \%)$ in contrast to previous reports of ECHO 9 infections. The number of white blood cells (WBC) in cerebrospinal fluid (CSF) ranged from 10 to $3,493 \mathrm{cells} / \mu \mathrm{l}$ (median; $412 \mathrm{cells} / \mu \mathrm{l}$ ). The neutrophils were more than $50 \%$ of the WBC in CSF in one-fourth of the patients at diagnosis. Enteroviruses were identified from CSF utilizing virus culture and enterovirus-specific RT-PCR, and ECHO-9 infection was determined by antibody titer of paired sera. Finally 44 patients were diagnosed virologically or serologically as aseptic meningitis caused by ECHO-9. Sequence analysis revealed that two strains of ECHO-9 isolated from CSF in this epidemic were closely related to ECHO-9 virulent strain Barty.
\end{abstract}

Key words ECHO-9, meningitis, sequence

\section{INTRODUCTION}

Aseptic meningitis is a severe nonbacterial infection of the central nervous system. Enteroviruses are major causative agent of aseptic meningitis of children in the summer. Among them echovirus type 9 (ECHO-9) is one of the most common agents associated with aseptic meningitis [1-5]. Outbreaks of ECHO-9 meningitis were reported in the late 1950s in the United States, Canada, England and Europe [6-13]. In Japan, epidemics of ECHO-9 meningitis were reported in Kumamoto [14] in 1967, and in Kagoshima prefecture [15] in 1990.

In the summer of 1997 , an epidemic of aseptic meningitis occurred in Fukuoka prefecture, Japan. Three hundred seventeen children with aseptic meningitis were admitted to the pediatric department of Kurume University and its affiliated hospitals. The present study reports the characteristics of the illness, certain clinical laboratory data, and serological and virological studies including reverse transcriptase polymerase chain reaction (RT-PCR). The causative agents of the aseptic meningitis were identified by isolation from a specimen of cerebrospinal fluid (CSF) and by examination of serum antibody titers. Sequences of isolated ECHO-9 were determined and also compared for the first time in order to identify the ECHO-9 lineage which caused the aseptic meningitis.

\section{PATIENTS AND METHODS}

\section{Patients}

The medical records of 317 aseptic meningitis patients at the Kurume University Hospital, Kurume University Medical Center, St. Mary's Hospital, Yame General Hospital and the Hospital of AmagiAsakura Medical Association between June and September of 1997 were reviewed. In this study, 
aseptic meningitis is defined as an acute illness clinically compatible with viral meningitis associated with CSF pleocytosis of more than 10 white blood cells $(\mathrm{WBC}) / \mu \mathrm{l}$. A lumbar puncture was performed on all patients, all of whom had negative bacterial cultures of CSF.

\section{Cells and viruses}

RD-18S, Hep-2 and Vero cells were maintained in Dulbecco's modified minimal essential medium (DMEM) supplemented with $10 \%$ fetal bovine serum, $100 \mathrm{U} / \mathrm{ml}$ penicillin $\mathrm{G}$ and $100 \mu \mathrm{g} / \mathrm{ml}$ streptomycin.

Virus isolation was performed from the CSF. One hundred $\mu$ l of CSF from aseptic meningitis patients were inoculated on RD-18S, Hep-2 and Vero cells. When cytopathic effect (CPE) of the cells appeared in 2 weeks, the cells were harvested and the viruses were identified with the pool of antibodies proposed by Lim and Benyesh-Melnik [16]. The isolated viruses were also examined by neutralization with antibodies against mumpsvirus. The isolated ECHO-9 were grown on RD-18S cells until the CPE was evident in more than $90 \%$ of the cells. Then, the cells were harvested and the supernatant was used as the viral stock after three cycles of freeze and thawing. Viral RNA was extracted using Sepa Gene (Sanko Junyaku) according to the company's protocol.

\section{Serum antibodies}

Sera were taken twice from each of 24 patients, at intervals of 3-21 days, and the serum antibody titer between the two samples was compared by neutralization assay. A fourfold or greater increase in the antibody titer between the acute phase and the convalescent sera was considered necessary for the serologic diagnosis of recent infection.

\section{$R T-P C R$ and sequence}

RT-PCR was performed using Ready-to-Go RTPCR kit (Pharmacia). Briefly, cDNA was synthesized at $37{ }^{\circ} \mathrm{C}$ for $10 \mathrm{~min}$ and at $42{ }^{\circ} \mathrm{C}$ for $30 \mathrm{~min}$ from $25 \mathrm{ng}$ of viral RNA using $1 \mathrm{ng} / \mathrm{ml}$ of random 9 mer (Takara) as a primer. After cDNA was synthesized, ECHO-9 sequences encoding a part of VP1 and 2A (903 bp) were PCR amplified using a primer pair of 5'-GGTAGGGTTGCTGACACAATACG-3' (nucleotide position 2481-2503 of ECHO-9 strain Barty) and 5'-CACATACACAGCTCCAGATTCTTGG-3' (nucleotide position 3349-3383 of ECHO-9 strain Barty) for 30 cycles under the conditions of denaturation at $94{ }^{\circ} \mathrm{C}$ for $1 \mathrm{~min}$, annealing at $50^{\circ} \mathrm{C}$ for $1 \mathrm{~min}$ and extension at $72^{\circ} \mathrm{C}$ for $1 \mathrm{~min}$, followed by final extension at $72{ }^{\circ} \mathrm{C}$ for $5 \mathrm{~min}$. Amplified fragments were purified through $1 \%$ agarose gel electrophoresis and ligated into pT7Blue-T vector (Novagen). The cloned plasmids were transformed in E.coli JM109 (Toyobo) and the plasmid DNA was purified using QIAprep spin (Qiagen).

Sequence was determined using Big-Dye cycle sequence kit (Perkin Elmer) from both directions by ABI PRISM 310 DNA sequencer (Perkin Elmer), and analyzed using Gene Works program (Inteli Genitics).

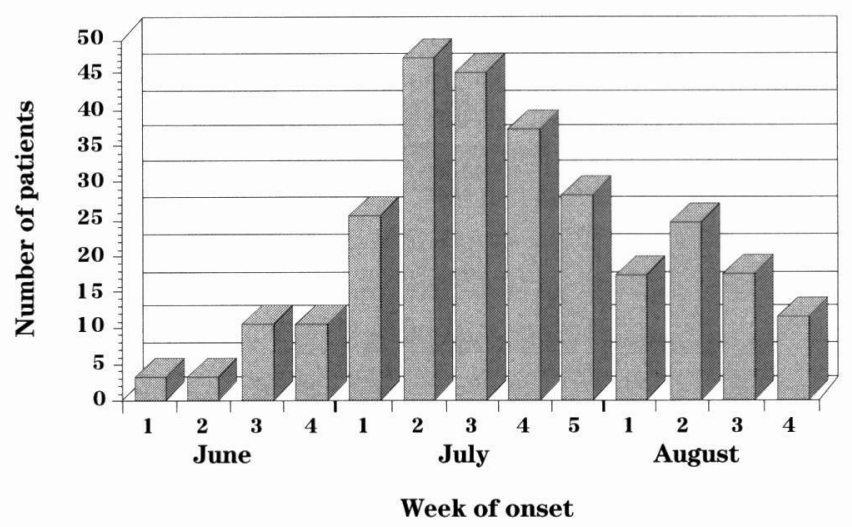

Fig. 1. Distribution of number of patients of aseptic meningitis according to week of onset of symptoms. Number of patients with aseptic meningitis between June and August 1997 was summarized weekly.

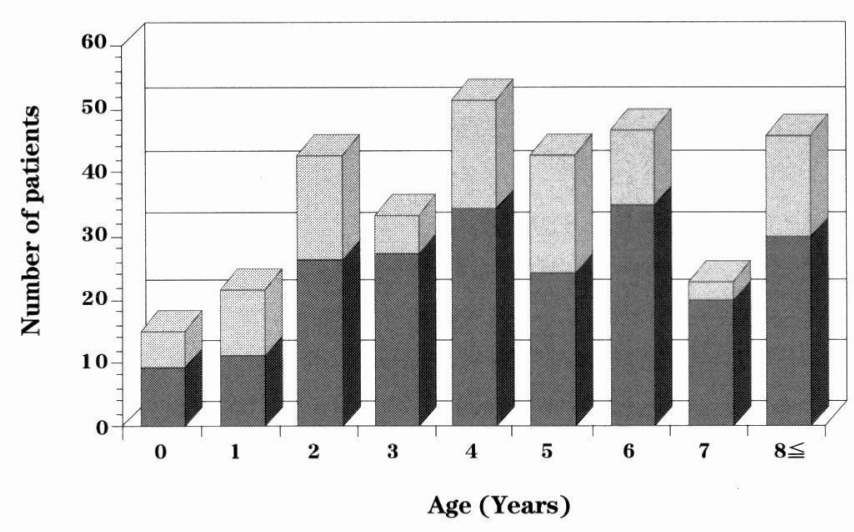

Fig. 2. Age distribution of 317 children with aseptic meningitis. Age and sex distribution of aseptic meningitis patients is indicated. Female is lightly shaded and male is dark shaded. 


\section{RESULTS}

\section{Epidemiology of aseptic meningitis}

Three hundred seventeen cases of aseptic meningitis in Chikugo area, Southern region of Fukuoka Prefecture, were diagnosed between June and August, 1997 (Fig. 1). The distribution of patients by age and sex is shown in Fig. 2. The age of the patients ranged from 1 month to 12 years and the highest incidence was in the 4-year-old children. The male: female ratio was 2.0:1.

\section{Clinical signs and symptoms}

All of the patients were febrile on admission, and $33.4 \%$ of them had a fever with two peaks (Table 1). The mean duration of fever was 7.6 days (standard deviation; \pm 3.5 ). Headache was present in $89.5 \%$ of the patients who were 3 years old and older (184 of 230 patients), and nausea and/or vomiting occurred in $85.6 \%$. Neck stiffness and Kernig's sign were observed in $58.9 \%$ and $10.9 \%$, respectively. Only $2.2 \%$ of the patients had skin rash. Febrile seizures occurred in 7 patients but there were no neurologic abnormalities present.

\section{Laboratory findings}

The mean peripheral WBC count was 11,162 cells $/ \mu 1$ (Table 2). Leukocytosis of $\geq 15,000$ cells $/ \mu 1$ was found in $35(11.3 \%)$ of 311 patients examined. The mean value of $\mathrm{C}$-reactive protein (CRP) was $0.74 \mathrm{mg} / \mathrm{dl}$ and $5.8 \%$ of the patients had more than $3.0 \mathrm{mg} / \mathrm{dl}$. The CSF findings are summarized in Table 3. The WBC in CSF (cWBC) ranged between 10 and 3,493 cells $/ \mu 1$ and the mean cWBC was 574 cells $/ \mu 1$. The median of cWBC counts among ages were not significantly different (data not shown). The differential cell count in CSF revealed that $75.5 \%$ of the patients had lymphocytosis of more than $50 \%$ at diagnosis (median; 5 days of illness), while predominance of neutrophils was seen in one-fourth of the patients (median, 2 days of illness).

The glucose concentration in CSF was $<40 \mathrm{mg} / \mathrm{dl}$ in $7(2.2 \%)$ of 313 patients examined, but was still more than half of the blood glucose concentration. The protein concentration in CSF was elevated over $100 \mathrm{mg} / \mathrm{dl}$ in $5(1.7 \%)$ of all the patients, and the highest was $173 \mathrm{mg} / \mathrm{dl}$.

Paired sera from 24 patients were examined. The antibody titer of 9 cases had more than fourfold increase of antibodies against ECHO-9, and one of them also had those against coxsackievirus B3. In
TABLE 1.

Clinical signs and symptoms of the patients on admission

\begin{tabular}{lcc}
\hline & cases & $\%$ \\
\hline $\begin{array}{l}\text { fever: } \\
\text { (duration of fever 7.6 } \pm \text { 3.5 days) } \\
\quad \text { two-peak fever }\end{array}$ & 317 & 100 \\
nausea and/or vomiting: & 106 & 33.4 \\
headache (over 3 years old): & 269 & 85.6 \\
neck stiffness: & 214 & 89.5 \\
Kernig's sign: & 181 & 58.9 \\
rash: & 34 & 10.9 \\
complication: febrile seizure & 7 & 2.2 \\
\end{tabular}

TABLE 2.

Laboratory results of the patients with aseptic meningitis on admission

\begin{tabular}{lrrc}
\hline \multicolumn{1}{c}{ Range } & cases & $\%$ & Mean \pm SD $^{*}$ \\
\hline WBC (cells/dL) & & & \\
$<10000$ & 146 & 46.9 & $11162.0 \pm 6371.8$ \\
$10000-<15000$ & 130 & 41.8 & \\
$\geq 15000$ & 35 & 11.3 & \\
& & & \\
CRP (mg/dL) & & & \\
$<1.0$ & 238 & 76.0 & $0.74 \pm 1.11$ \\
$1.0-<3.0$ & 57 & 18.2 & \\
$\geqq 3.0$ & 18 & 5.8 & \\
\hline
\end{tabular}

* standard deviation

TABLE 3.

Findings in cerebrospinal fluid on admission

\begin{tabular}{lrrrr}
\hline \multicolumn{1}{c}{ Range } & cases & $\%$ & Median & Mean \pm SD $^{*}$ \\
\hline Cell count (cells/ $\mu \mathrm{L})$ & & & & \\
$\quad<50$ & 45 & 14.2 & 412 & $573.9 \pm 598.8$ \\
$50-<1000$ & 212 & 67.1 & & \\
$\geqq 1000$ & 59 & 18.7 & & \\
& & & & \\
Glucose (mg/dL) & & & & \\
$<40$ & 7 & 2.2 & 61.0 & $62.9 \pm 14.6$ \\
$\geqq 40$ & 306 & 97.8 & & \\
& & & & \\
Protein (mg/dL) & & & & \\
$<45$ & 225 & 71.8 & 36.0 & $38.7 \pm 20.6$ \\
$45-<100$ & 83 & 26.5 & & \\
$\geqq 100$ & 5 & 1.7 & & \\
\hline
\end{tabular}

* standard deviation 
conclusion, 44 patients were diagnosed as aseptic meningitis by ECHO-9.

One hundred ninety-eight CSF samples were inoculated on cultured cells and CPE was observed in 112 samples $(56.5 \%)$. Forty-two samples which developed CPE were further tested for virus identification. Among them, ECHO-9 were isolated in 35 samples, coxsackievirus B5 were isolated in 6 samples, and coxsackievirus B3 was isolated in one sample.

\section{Sequence comparison of the two ECHO-9 isolates}

Figures 3 and 4 show the determined nucleotide sequences corresponding to genome positions 24813383 of strain Barty and the deduced amino acid sequences corresponding to positions of 581-881 of ECHO-9 two isolates, No. 66 and 106, strain Barty (DDBJ, EMBL and GenBank account No. X92886) [17] and strain Hill (DDBJ, EMBL and GenBank account No. X84981) [18].

No. 66 and No. 106 have the same genome

\begin{tabular}{|c|c|c|c|c|c|c|c|c|c|c|c|}
\hline Strain Barty & GGTAGGGTTG & CTGACACAAT & ACGCAGTGGG & ССТТСТАACT & CTGAAGCGGT & CCCGGCACTC & ACAGCTGCTG & AGACTGGACA & САССТСACAA & GTGGTGCCCA & 2580 \\
\hline No. 66 & $\ldots \ldots \ldots$ & $\ldots \ldots \ldots$ & $\ldots \ldots \ldots$ & …… & .C.G.A. & T..C.G... & ..... . & A. . . . . & $\ldots \ldots \ldots$ & .A.A... & 100 \\
\hline No. 106 & $\ldots \ldots \ldots$ & $\ldots \ldots \ldots$ & n.m. & ..... . & .C. .G.A. & T..C. G... & ...... & A. $\ldots \ldots$ & $\cdots \cdots \cdots$ & A. A... & 100 \\
\hline Strain $\mathrm{Hill}$ & .A..... & A....C. & $\ldots \ldots \ldots \mathrm{A}$ & $\ldots \ldots$. . . & ...G.A. & G..A.T... & $\ldots \ldots c$ & ........ & $\ldots \ldots \ldots$ & ...... & 2579 \\
\hline Strain Barty & GTGACACTAT & GCAAACTAGG & CACGTGAAAA & АTТАCСACTC & TCGATCCGAG & TCCACTATAG & AGAACTTTTT & GTGTAGATCG & GCTTGTGTGC & GGATGGCCAA & 2680 \\
\hline No. 66 & $\ldots \ldots \ldots$ & $\ldots \ldots \ldots$ & $\ldots \ldots \ldots$ & $\ldots$. $\ldots$ & C..G...A & ........ & A....CC. & ...C. GG. & $\ldots \ldots \ldots$ & . T... T. & 200 \\
\hline No. 106 & $\ldots \ldots \ldots$ & $\ldots \ldots \ldots$ & $\ldots \ldots \ldots$ & $\ldots$ т.... & C..G....A & ...с... & .A. $\ldots$ CC. & ...C. GG. & $\ldots \ldots \ldots$ & . T.... T. & 200 \\
\hline Strain Hill & .c....... & ......... & . . . G. & ..... T. & A.C. . . A & …с. . & A. $\ldots \ldots$ & A. $\ldots \ldots$ A & . C...... & A. . . A. & 2679 \\
\hline Strain Barty & GTATGAAGCA & AGGGGTGACC & CTGAGAGCAC & AGATCGCTTT & GATGCATGGG & AGATAAGCGT & GCGTGACATG & GTTCAAATGC & GCCGCAAGTG & TGAAATGTTC & 2780 \\
\hline No. 66 & $\ldots$. G... & ....CA... & .C.... T. & T........ & $\ldots$. . . . & $\ldots \ldots$ A & A..C.... & . С.... & $\cdots \ldots \ldots$ & $\ldots G \ldots$ T & 300 \\
\hline No. 106 & $\ldots \ldots$ G. & .A. .CA... & .С...T. & T. $\ldots \ldots$ & ....G.... & …A. & A. .C..... & .С... T... & $\ldots \ldots \ldots$ & ..G....T & 300 \\
\hline Strain Hill & $\ldots$. G. & . . . CA.C. & $-\ldots$ A.... & T...... & $\ldots \ldots \ldots$ & $\cdots \cdots \cdots$ & $\ldots$. . . . . & .A... . . & A. $\ldots \ldots$ & C..G..... & 2776 \\
\hline Strain Barty & ACGTACCTAC & GTTTCGACGT & AGAGGTCACG & TTCGTAATTA & CTAGTTACCA & GCATCAAGGA & TC--CATTAA & TCAAGACATG & CCCCCGATGA & C--TCATCAA & 2876 \\
\hline No. 66 & .A..T.G. & .С. . .... & G.A....A & .Т.A.А. & $\ldots \ldots \ldots$ & $A \ldots \ldots G$ & A. $-\cdots \cdots$ & $c \ldots \ldots$ & $\ldots$ A. . . &.$-\ldots$. . . & 396 \\
\hline No. 106 & .A...T.G. & .С. T.... & G.A....A & .T.A.A. & $\ldots \ldots \ldots$ & A. $\ldots \ldots$ G & A. $-\ldots \ldots$ & $c \ldots \ldots \ldots$ & … A. & $\cdot-\ldots$. . . & 396 \\
\hline Strain Hill & .A. . . G. & A. . T. . . & T.A....A & . . . . . . & ...... . & $\ldots G C \ldots . C$ & A.TT.T.C. & . С... & $-\ldots$ T. . & .GCC..C. . G & 2875 \\
\hline Strain Barty & ATAATGTACA & TACCACCCGG & TGGCCCATTC & CCAAAGAAAG & TGGATGGTAT & TGAGTGGCAG & ACCTCGACCA & ACCCTAGTAT & ATTTTGGACT & GAAGGGAATG & 2976 \\
\hline No. 66 & $\ldots \ldots \ldots$ & A. . . . & C....CA. & .T.... & $\ldots \ldots c \ldots$ & & .A.A.... & ........ & $\ldots \ldots \ldots c$ & & 496 \\
\hline No. 106 & $\cdots \cdots \cdots$ & .A. $\ldots \ldots$ & C....CA. & .T....G. & $\ldots \ldots c \ldots$ & $\cdots \cdots$ & .A. A. . . & .... . . . & $\ldots \ldots \ldots$ & $\ldots \ldots \ldots$ & $496^{\circ}$ \\
\hline Strain Hill & $\cdots \cdots \cdots$ & .C..G.T. & T.T. TA. & $\ldots \ldots G$ & & $C \ldots \ldots A$ & .A.A... & . T. A... & $\ldots \ldots \ldots c$ & . G. & 2975 \\
\hline Strain Barty & CTCCGCCTAG & GATGTCCATT & CCGTTTATTA & - GCATTGGCAA & TGCCTACAGC & AGCTTTTATG & ATGGGTGGTC & ACATTTTGAT & AGTAAAGGTG & CCTACGGTTT & 3075 \\
\hline No. 66 & .C...... & $\ldots \ldots \ldots$ & .A..... & $\cdots \cdots \cdots$ & $\ldots$ т. $\ldots$ & $\ldots \ldots c$ &.$c \ldots \ldots$ & T. . . . C & .c..... & … .А. & 596 \\
\hline No.106 & .C.A.... & $\cdots \cdots \cdots c$ & .A....C. & $\ldots \ldots \ldots$ & $\ldots$ T. . . & $\ldots \ldots \ldots$ &.$C \ldots \ldots$ & $m \ldots \ldots c$ & . C..... & … . A. & 596 \\
\hline Strain Hill & .A. T.... & $\ldots \ldots \ldots$ & .......... & .T....... & …..m & .Т..... & ‥ т..... & ....... & .C. G.A. & .T.T.A. & 3075 \\
\hline Strain Barty & CAACACCTTG & AACAAAATGG & GGCATATTTA & CTGCAGGCAC & GTAAACAAAG & AGACACCCGC & TGAGGTCACC & AGTMACATTA & GGATTTACTT & CAAGCCTAAG & 3276 \\
\hline No. 66 & $\ldots$. . & $\ldots$ G... & $\ldots \subset \ldots$ & $\ldots$. $\ldots$. & $\ldots G \ldots$ G. & $\ldots$..... & $\mu_{\mu}$ & $\ldots \ldots c$ & $\cdots \cdots \cdots$ & . A. C. A & 596 \\
\hline No. 106 & …. T. & $\ldots$ G... & ... & $\ldots$ Т.... & $\ldots G \ldots$ G. & $\ldots$..... & $\cdots \cdots \cdots$ & $\ldots \ldots c$ & $\ldots \ldots \ldots$ & .A. C. A & 596 \\
\hline Strain Hill & $\ldots \cdots C \cdot A$ & $\ldots$ T.... & .A.C..C. & $T \ldots \ldots T$ & .т..... & ...G.AA. & AA. . . T . & $\ldots \ldots \ldots$ & $\ldots$..... & T....A & 3175 \\
\hline Strain Barty & CACATCAGAG & CGTGGGTACC & AAGACCACCG & CGATTGTGTC & AGTATAAGAP & CAAGGCAAAC & GTGAACTTTG & AAGCCACGGC & GTTCACTGAG & ACGCGTGATA & 3276 \\
\hline No. 66 & .T.... & ....G. & $\cdots \ldots \ldots$ & $\ldots G \ldots \ldots$ & ...C.A. & T.A..G.T & $\ldots \ldots \ldots$ & .C.A..C. & AG...C.A & A. .G.GA. & 796 \\
\hline No. 106 & $\ldots T \ldots G$ G. & ....G. & $\cdots \cdots \cdots$ & .G. . . . & ... . A. & T.A. . G.T & & .C. A. C.. & AG...C.A & .A.G.GA. & 796 \\
\hline Strain Hill & .TG.T... & .A....C. & ....G.A & $\ldots c \ldots$ & .А. С.T... & ..... . & & $\ldots \ldots c \ldots$ & AG...A. .C & $\ldots c \ldots \ldots$ & 3275 \\
\hline Strain Barty & CCATCAACAC & TGTCCCTGTA & TCAAATCACG & GGAGTGGACG & CCGCGGTGAT & TTGGCCGCGC & TGAGCACACA & TGGCGCTTTT & GGCCAAGAAT & CTGGAGCTGT & 3375 \\
\hline No. 66 & T. . A.... & $\ldots \ldots \ldots G$ & . G. . . .T. & .C..C.AT. & $\ldots$. $\ldots$. & . .T.A. & .A..... & $\ldots$. TG. . C & $\cdots \cdots \cdots$ & $\cdots \cdots \cdots$ & 396 \\
\hline No. 106 & T.A.... & $\ldots \ldots \ldots G$ & .G.C.T. & .C. С.AT. & $\ldots$. . . C & ... T. A. & .A. $\ldots$ & ....TG. .C & $\cdots \cdots \cdots$ & $\cdots \cdots \cdots$ & 396 \\
\hline Strain Hill & $\ldots \ldots$ T. & A....GC.G & ....CA... & .AGTCA.TA. & G-- - - - & - & --------- & -.T.G.AC & .T. .TC... & .A. .C. .ACG & 3345 \\
\hline
\end{tabular}

Strain Barty GTATGTG 3383

No. $66 \quad \ldots \ldots \ldots 903$

No.106 $\quad \ldots \ldots .6903$

Strain Hill T.... 3352

Fig. 3. Nucleotide sequences of ECHO-9. Only differences from the reference strain, Barty, are indicated. Dots indicates the same nucleotide sequence as that of strain Barty. The positions of the PCR primers (5'GGTAGGGTTGCTGACACAATACG-3' and 5'CACATACACAGCTCCAGATTCTTGG-3') are underlined. A dash indicates a deletion of nucleotides. The position of VP1 and 2A protein is indicated in the figure. 
length as strain Barty in the PCR amplified region where most of capsid protein, VP1 (genome positions 2481-3365 and amino acid positions 581-875), and part of 2A protein (genome positions 3366-3383 and amino acid positions 876-881) are encoded. There is only one nucleotide difference at the genome position 2693 between No. 66 and 106. The deduced amino acid sequences are identical between the two. There are $14.8 \%$ of nucleotide difference between No. 66 and strain Barty, and $15.0 \%$ nucleotide difference between No. 106 and strain Barty, respectively. There are $3.7 \%$ amino acid differences among No. 66, No. 106 and strain Barty.
There were 30 nucleotides loss in strain Hill (genome positions 3318-3347 of strain Barty), resulting loss of 10 amino acids in the same frame (amino acid positions 860-869 of strain Barty). There were four nucleotide gaps at the positions 2701, 2714, 2718 and two nucleotides insertion at the position between 2842 and 2843, and 2869 and 2870 in strain Hill, resulting in frame shift of amino acid at positions $654-660$ and 700-710.

Figure 5 shows the dendrogram constructed from nucleotide (A) and amino acid sequences (B) by UPGMA method [19].

\begin{tabular}{|c|c|c|c|c|c|c|c|}
\hline strain & Barty & GRVADTIRSG & PSNSEAVPAI & TAAETGHTSQ & VVPSDTMQTR & HVKNYHSRSE & 630 \\
\hline No. 66 & & $\cdots \cdots \cdots$ & $\ldots \ldots \ldots$ & $\ldots \ldots \ldots$ & $\ldots \ldots \ldots$ & $\ldots \ldots \ldots$ & \\
\hline No. 106 & & $\ldots \ldots \ldots$ & $\ldots \ldots \ldots$ & $\ldots \ldots$ & $\ldots \ldots \ldots$ & $\ldots \ldots$ & \\
\hline Strain & Hill & $\ldots \ldots \ldots$ & $\ldots \ldots \ldots$ & $\cdots$ & $\ldots \ldots \ldots$ & $\ldots \ldots \ldots$ & \\
\hline Strain & Barty & STIENFLCRS & ACVRMAKYEA & RGDPESTDRF & DAWEISVRDM & VQMRRKCEMF & 680 \\
\hline No. 66 & & $\ldots \ldots \ldots$ & $\ldots \ldots \ldots$ & $\ldots \ldots \ldots$ & $\ldots \ldots$.... & $\ldots$ L...... & 100 \\
\hline No. 106 & & $\ldots \ldots A$ & $\ldots \ldots \ldots$ & $\ldots \ldots \ldots$ & $\ldots \ldots$ I... & $\ldots$ L...... & 10 \\
\hline Strain & $\mathrm{Hill}$ & $\ldots \ldots \ldots$ & $\ldots \ldots \ldots$ & . . LIKALT-L & $\ldots \ldots \ldots$ & $\ldots$ I...... & \\
\hline Strain & Barty & TYLRFDVEVT & FVITSYQHQG & SINQDMPPM- & THQIMYIPPG & GPFPKKVDGY & 129 \\
\hline No. 66 & & $\ldots \ldots \ldots$ & $\ldots \ldots \ldots$ & T...... & $\ldots \ldots \ldots$ & $\ldots I \ldots \ldots$ & 149 \\
\hline No. 106 & & $\ldots \ldots \ldots$ & $\ldots \ldots \ldots$ & T...... & $\ldots \ldots \ldots$ & $\ldots I \ldots \ldots$ & 149 \\
\hline strain & $\mathrm{Hill}$ & $\ldots \ldots \ldots$ & ....RR. & TSSIQIC.YD & A........ & $\ldots I \ldots \ldots$ & \\
\hline Strain & Barty & EWQTSTNPSI & FWTEGNAPPR & MSIPFISIGN & AYSSFYDGWS & HFDSKGAYGF & 779 \\
\hline No. 66 & & $\cdots \cdots \cdots$ & $\ldots \ldots \ldots$ & $\ldots \ldots \ldots$ & $\cdots \cdots$ & $\ldots \ldots \ldots$ & 199 \\
\hline No. 106 & & $\ldots \ldots \ldots$ & $\ldots \ldots \ldots$ & $\ldots \ldots \ldots$ & $\ldots \ldots \ldots$ & $\ldots \ldots \ldots$ & 199 \\
\hline Strain & $\mathrm{Hill}$ & $\cdots \cdots \cdots$ & $\ldots \ldots$ & $\ldots \ldots$ & $\ldots \ldots \ldots$ & $\ldots \ldots \ldots$ & 78 \\
\hline Strain & Barty & NTLNKMGHIY & CRHVNKETPA & EVTSYIRIYF & KPKHIRAWVP & RPPRLCQYKN & 829 \\
\hline No. 66 & & $\ldots \ldots \ldots$ & $\ldots \ldots \ldots$ & $\ldots \ldots \ldots$ & $\ldots \ldots \ldots$ & $\ldots \ldots \ldots$ & 249 \\
\hline No. 106 & & $\ldots \ldots \ldots$ & $\ldots \ldots \ldots$ & $\ldots \ldots \ldots$ & $\ldots \ldots \ldots$ & $\ldots \ldots \ldots$ & 249 \\
\hline Strain & $\mathrm{Hill}$ & $\cdots \cdots \cdots$ & $\ldots \ldots \ldots \mathrm{T}$ & K........ & $\ldots v \ldots$ & $\ldots \ldots$ M. & 820 \\
\hline Strain & Barty & KANVNFEATA & FTETRDTINT & VPVSNHGSGR & RGDLAALSTH & GAFGQESGAV & 879 \\
\hline No. 66 & & ........ & V...G... & $\ldots \ldots$. D. & $\ldots \ldots$. . . & $. \quad . \ldots \ldots$ & 299 \\
\hline No. 106 & & $\ldots$..... & V....G... & $\ldots \ldots \ldots$ & $\ldots \ldots$. . . &.$V \ldots \ldots$ & 299 \\
\hline Strain & $\mathrm{Hill}$ & $\cdots \cdots \cdots$ & V.D...... & ..L.T.VS. & -------- & $\ldots \mathrm{Y} . \mathrm{HQ} \ldots \mathrm{R}$ & 869 \\
\hline train & Barty & 881 & & & & & \\
\hline No. 66 & & .. 301 & & & & & \\
\hline No. 106 & & .. 301 & & & & & \\
\hline Strain & $\mathrm{Hill}$ & . $\quad 871$ & & & & & \\
\hline
\end{tabular}

Fig. 4. Amino acid sequences of ECHO-9. Amino acid sequences of ECHO-9 are presented by one-letter code. Only differences from the reference strain, Barty, are indicated. Dots indicates the same amino acid sequence as that of strain Barty. A dash indicates a deletion of amino acids. The position of VP1 and 2A protein is indicated in the figure. 

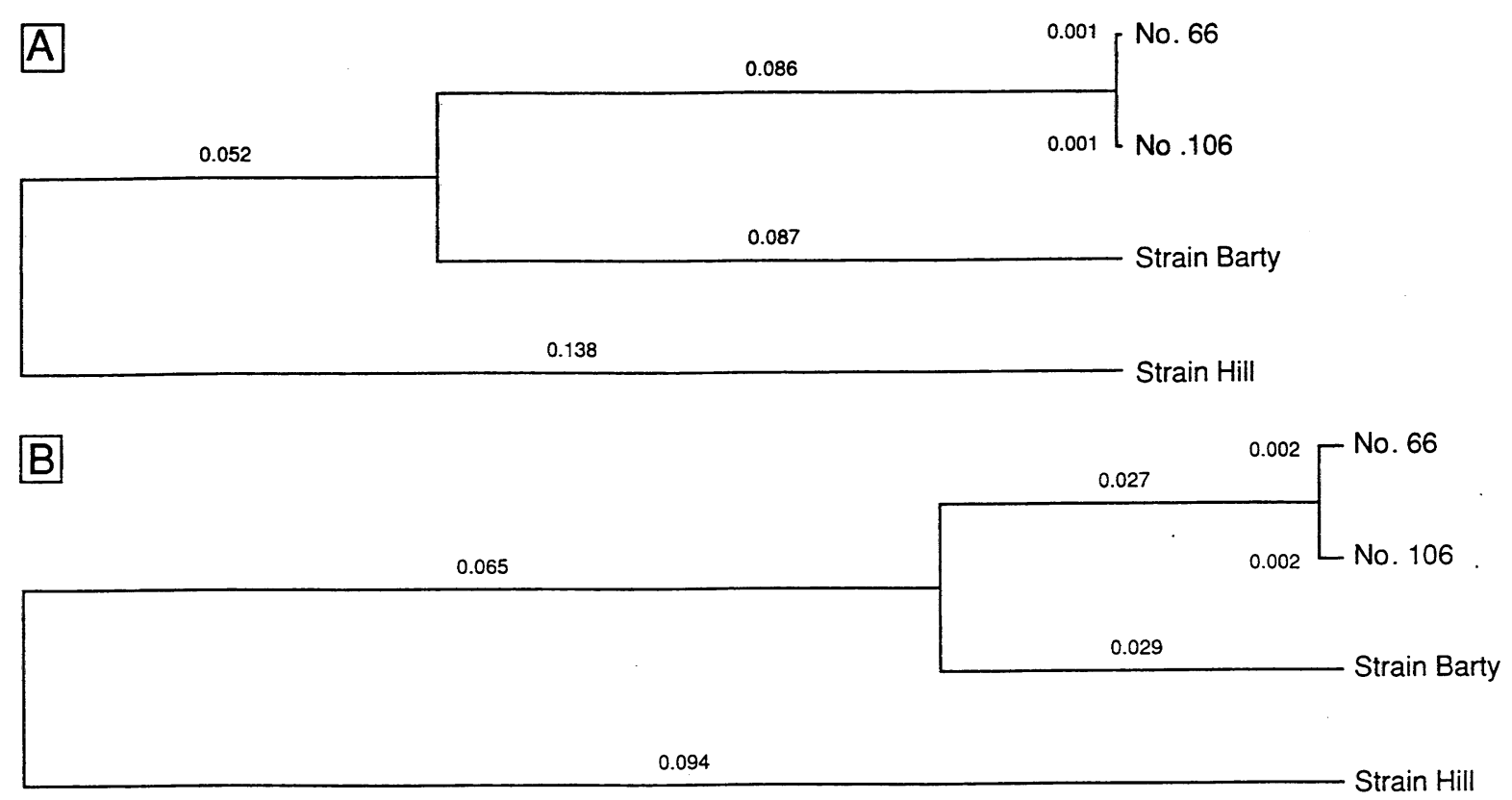

Fig. 5. Evolutionary trees of ECHO-9. Evolutionary trees of ECHO-9 No. 66, No. 106, strain Barty and Hill were constructed by nucleotide (A) and amino acid (B) sequences using UPGMA [19]. Number indicates the calculated genetic distance of each branch.

\section{DISCUSSION}

The epidemics of aseptic meningitis in the summer are caused mainly by enteroviruses. A prospective study in Baltimore, in the United States, confirmed that more than $90 \%$ of communityacquired cases of viral meningitis were caused by group $\mathrm{B}$ coxsackieviruses; coxsackievirus serotype B2 and B5, and echoviruses; echovirus serotype 4, 6, $9,11,16$, and 30 [20]. Three hundred seventeen cases of aseptic meningitis of children in the southern region of Fukuoka prefecture, Japan, were examined in the summer of 1997 and ECHO-9 was identified in 44 cases serologically or by virus isolation. Epidemics of aseptic meningitis caused by ECHO-9 in Europe and North America were reported in the late 1950s [6-13]. In Japan, epidemics of aseptic meningitis due to ECHO-9 in Kumamoto (the neighboring prefecture of Fukuoka) and Kagoshima (the neighboring prefecture of Kumamoto) prefectures were reported in 1967 and 1990, respectively $[14,15]$. In the present study, frequencies of neck stiffness (58.9\%), Kernig's sign (10.9\%), and skin rash $(2.2 \%)$ were lower than in the previous reports $[3,5,6,8,11,15]$. It has been reported that one-third to one-half of the patients with ECHO-9 meningitis had skin rash [3,21,22].

Although some reports have suggested a moderate risk of long-term neurologic and cognitive sequelae for infants who suffered viral meningitis at an early age $[23,24]$, recent prospective studies of more patients have demonstrated virtually no detectable effects $[25,26]$, including the cases with neurologic findings in the acute stage [27]. In this study, all the patients, including young infants, recovered spontaneously without any complications. Several epidemics of enteroviral meningitis were reported with very different age-group susceptibility $[3,4,28,29]$. Such variations in the epidemiology of enterovirus infections are not well understood. A sero-epidemiologic study of an outbreak of ECHO-9 meningitis in Japan in 1990 indicated that accumulation of susceptible infants and young children may have predisposed to the epidemic [15]. Such strain variation and the increase in newly susceptible young children may contribute to the spread of specific enterovirus infection among human populations. Intensive analysis of outbreaks of viral meningitis should be continued in order to confirm the clinical characteristics of ECHO-9 infection.

It was reported previously that the predominance of neutrophils in the CSF lasted no longer than 24 
hours [30] and that cell count in the CSF decreased with patient age $[15,31]$. In this study the period of the shift of WBC to lymphocyte predominance was observed on the second day of illness or later, and the median of WBC count in CSF did not increase in any age groups. In early stage of enterovirus meningitis, the reason of predominance of neutrophils in CSF is not well known. A study on the measurement of granulocyte colony-stimulating factor (GCSF) in CSF revealed that the concentration of GCSF in CSF of enterovirus meningitis was significantly higher than in CSF of mumps meningitis [32]. Some cytokines may play an important role in the percentage of neutrophils in CSF.

Sequences of the isolated ECHO-9 were determined in order to find out the characteristic genome structure which would explain the unique clinical feature of the aseptic meningitis in this outbreak. Sequence analysis revealed that two strains of ECHO-9, No. 66 and 106, isolated from the recent meningitis patients in Japan were closely related to echovirus-9 virulent strain Barty which was also isolated from a meningitis patient (Figs 5 and 6) [17]. No. 66 and No. 106 were almost identical in their genome sequence of VP1 region. Their amino acid differences from strain Barty were seen between conserved amino acids; $640 \mathrm{~S}$ to $\mathrm{A}, 667 \mathrm{~V}$ to I, 671 $\mathrm{M}$ to $\mathrm{L}, 701 \mathrm{~S}$ to $\mathrm{T}, 722 \mathrm{~F}$ to I, $836 \mathrm{E}$ to $\mathrm{D}, 840 \mathrm{~F}$ to $\mathrm{V}, 845 \mathrm{D}$ to $\mathrm{G}, 858 \mathrm{G}$ to $\mathrm{D}, 867 \mathrm{~S}$ to $\mathrm{N}$, and $871 \mathrm{~A}$ to V.

A virulent strain Hill which was isolated from a healthy child had a 10 amino acid deletion in the Cterminal region of VP1 protein, where one of two RGD sequences of VP1 is localized [33,34]. RGD sequences of VP1 protein are the binding sites of echoviruses to the host cell receptor, VLA-2, which is a member of the integrin family. The lack of a second RGD sequence is the major difference between virulent and avirulent strains of ECHO-9.

In this study, unique genome structure and genetic lineage of ECHO-9 which caused aseptic meningitis were identified from the limited data. However, gene structure which may be related with infrequency of skin rash remains to be elucidated.

ACKNOWLEDGMENTS: The author thanks Dr. N. Tsumura for isolation of ECHO viruses, Drs. K. Masunaga and Y. Ohtsu for RT-PCR and sequence, and Drs. H. Kato and T. Toyoda for critical reading of the manuscript.

\section{REFERENCES}

1. Frust WD. Outbreak of aseptic meningitis due to ECHO-
9 virus. Tex Med 1967; 63:76-79.

2. Lennette EH, Magoffin RL, Calf B, and Knouf EG. Viral central nervous system disease. JAMA 1962; 179:687695.

3. Feigin RD, and Cherry JD. Enteroviruses: polioviruses (poliomyelitis), coxsackieviruses, echoviruses, and enteroviruses. In: Textbook of Pediatric Infectious Disease, 2nd ed., ed. Cherry JD, Saunders, Philadelphia, pp 1705-1753, 1992.

4. Krugman S, Katz SL, Gershon AA, and Wilfert CM. Enteroviral infection. In: Infectious Disease of Children, 9th ed., Mosby, St. Louis, pp 68-87, 1992.

5. Singer JI, Maur PR, Riley JP, and Smith PB. Management of central nervous system infections during an epidemic of enteroviral aseptic meningitis. J Pediatr 1980; 96:559-563.

6. Rotem CE. Meningitis of virus origin. Lancet 1957; 1:502-504.

7. Stornes PB. Isolation of ECHO virus type 9 during an outbreak of meningo-encephalitis. Br Med J 1958; 2:1514.

8. Jamieson WM, Kerr M, and Sommerville RG. Echo type-9 meningitis in East Scotland. Public Health 1958; 15:581-583.

9. Kibbigk S, and Enders JF. Disease due to echo virus type 9 in Massachusetts, 1958. N Engl J Med 1958; 259:482484.

10. Frothingham TE. Echo virus type 9 associated with three cases simulating meningococcemia. N Engl J Med 1958; 259:484-485.

11. Solomon P, Weinstein L, Chang TW, Aretenstein MS, and Ambrose CT. Epidemiologic, clinical, and laboratory features of an epidemic of type 9 echo virus meningitis. Pediatrics 1962; 266:609-619.

12. Lepow ML, Carver DH, Wright HT Jr, Woods WA, and Robbins FC. A clinical, epidemiologic and laboratory investigation of aseptic meningitis during the four-year period, 1955-1958: I. Observations concerning etiology and epidemiology. N Engl J Med 1962; 266:1181-1187.

13. Lepow ML, Coyne N, Tompson LB, Carver DH, and Robbins FC. A clinical, epidemiologic and laboratory investigation of aseptic meningitis during the four-year period, 1955-1958: II. The clinical disease and its sequelae. N Engl J Med 1962; 266:1188-1193.

14. Shingu M, Honda M, Sonoda I, and Nakagawa $Y$. Echovirus type 9 meningitis epidemic in Kyushu during the summer of 1967. Kurume Med J 1968; 15:21-30.

15. Gondo K, Kusuhara K, Take H, and Ueda K. Echovirus type 9 epidemic in Kagoshima, southern Japan: seroepidemiology and clinical observation of aseptic meningitis. Pediatr Infect Dis J 1995; 14:787-791.

16. Lim KA, and Benyesh-Melnick M. Typing of viruses by combinations of antiserum pools: application to typing of enteroviruses (Coxackie and echo). J Immunol 1960; 84:309-317.

17. Zimmermann H, Eggsr HJ, and Nelsen-salz B. Molecular cloning and sequence determination of the complete genome of the virulent echovirus 9 strain Barty. Virus Genes 1996; 12:149-154.

18. Zimmermann H, Eggsr HJ, Zimmermann A, and Nelsen- 
salz B. Complete nucleotide sequence and biological properties of an infectious clone of prototype echovirus 9. Virus Research 1995; 39:311-319.

19. Nei M. Molecular Evolutionary Genetics. Columbia University Press, New York, N.Y., pp 293-298, 1987.

20. Berlin LE, Rorabaugh ML, Heldrich F, Roberts K, Doran T et al: Aseptic meningitis in infants less than two years of age: Diagnosis and etiology. J Infct Dis 1993; 168:888-892.

21. Wesslen T, Eriksson S, Ehinger A et al. Epidemic of aseptic meningitis associated with Echo virus type 9. Arch Ges Virusfrosch 1958; 8:183-191.

22. Arai M. Aseptic meningitis. New Encyclopedia of Pediatrics and Related Medical Science, 20A. Nakayama Press, Tokyo, 1982.

23. Sells CJ, Carpenter RL, and Ray CG. Sequelae of central-nervous-system enterovirus infections. N Engl J Med 1975; 293:1-4.

24. Abzug MJ, Levin MJ, and Rotbart HA. Profile of enterovirus disease in the first two weeks of life. Pediatr Infect Dis J 1993; 12:820-824.

25. Rorabaugh ML, Berlin LE, Rosenberg L et al. Absence of neurodevelopmental sequelae from aseptic meningitis. Society for Pediatric Research, Baltimore, 1992.

26. Bergman I, Painter MJ, Wald ER, Chiponis D, Holland AL et al. Outcome in children with enteroviral meningitis during the first year of life. J Pediatr 1987; 110:705709 .
27. Rorabaugh ML, Berlin LE, Heldrich F et al. Aseptic meningitis in infants younger than 2 years of age: Acute illness and neurologic complications. Pediatrics 1993; 92:206-211.

28. Cheeseman SH, Hirsch MA, Keller EW, and Keim DE. Fatal neonatal pneumonia caused by echovirus 9. Am J Dis Child 1977; 131:1169.

29. Zuckerman MA, Sheaff M, Martin JE, and Gabriel CM. Fatal case of echovirus type 9 encephalitis. J Clin Pathol 1993; 46:865-866.

30. Amir J, Harel L, Frydman M, Handsher R, and Varsano I. Shift of cerebrospinal polymorphonuclear cell percentage in the early stage of aseptic meningitis. J Pediatr 1991 ; 119:938-941.

31. Jarvis WR, and Tucker G. Echovirus type 7 meningitis in young children. Am J Dis Child 1981; 135:1009-1012.

32. Yokoyama T, Oda M, Akazawa A et al. Characteristics of cerebrospinal fluid in enteroviral and mumps meningitis. J Jpn Pediatr Soc 1995; 99:1587-1592.

33. Ramos-Alvarez $M$, and Sabin AB. Characteristics of Poliomyelitis and other enteric viruses recovered in tissue culture from healthy American children. Proc Soc Exp Biol Med 1954; 87:655-661.

34. Zimmermann H, Eggera HJ, and Nelsen-salz B. Cell attachment and mouse virulence of echovirus 9 correlate with an RGD motif in the capsid protein VP1. Virology 1997; 233:149-156. 